\title{
A referendum on the reform of the House of Lords?
}

\author{
MARK RYAN ${ }^{*}$
}

Senior Lecturer in Constitutional and Administrative Law,
Coventry University

A referendum may be defined as the holding of a ballot in which electors are called upon, not to elect, but to pass judgement on a particular question. (Lord Norton of Louth, Professor of Government and Director of the Centre for Legislative Studies, University of Hull $)^{1}$

$\mathrm{T}$ he question of reform of the House of Lords has remained an unresolved, perennial constitutional issue since the preamble to the 1911 Parliament Act provided that it was an essentially temporary measure, pending the introduction of members on a 'popular' (i.e. elected) basis. The latest attempt at long-term reform in July 2012 involved MPs giving a second reading to the House of Lords Reform Bill which proposed an 80 per cent elected House. The Bill was abandoned by the Coalition government shortly afterwards, however, because of a failure of MPs to agree a programme motion setting out the timetable for its passage through the Commons. A draft version of this Bill had received pre-legislative scrutiny by a Joint Committee which had recommended that a referendum take place on the decision to establish an elected second chamber. ${ }^{2}$ Although in its official response, the Coalition government rejected this recommendation, ${ }^{3}$ the purpose of this paper is to argue that a national referendum should nevertheless have taken place. Not only was this a lost opportunity in 2012, but also that, when the issue of fundamental Lords reform next appears on the political agenda, a national referendum should be held. In fact, the concept of a referendum on constitutional issues has some weighty provenance as it was proposed

* BA, MA, PGCE, Barrister (non-practising). This paper is based upon a conference paper delivered by the author to the Society of Legal Scholars conference at Nottingham University in September 2014 and a written submission to the Joint Committee on the Draft House of Lords Reform Bill, Report, vol III, HL Paper 284III, HC 1313-III (TSO 2012) 172. In this written evidence, which was quoted by the Joint Committee in the body of its report (vol I, para 376), the author advocated a referendum on Lords reform. This view was repeated by the author in his Oral Evidence in July 2012 to the House of Commons Political and Constitutional Reform Select Committee, Ensuring Standards in the Quality of Legislation HC 85 (TSO 2013) Q 199. In addition, in September 2011 the author lodged an e-petition on the HM government website calling for a referendum on the Coalition government's Draft House of Lords Reform Bill as to whether the second chamber should be largely or wholly elected.

1 Phillip Norton, The Constitution in Flux (Martin Robertson 1982) 213.

2 Joint Committee on the Draft House of Lords Reform Bill, Report, vol I, HL Paper 284-I, HC 1313-I (TSO 2012) para 385.

3 Government Response to the Report of the Joint Committee on the Draft House of Lords Reform Bill Cm 8391 (TSO 2012) 32. 
by Professor Dicey over a century ago. ${ }^{4}$ As a useful backdrop to the debate, it is rather apposite that in April 2010 the House of Lords Select Committee on the Constitution published a wide-ranging report on referendums ${ }^{5}$ in the UK. ${ }^{6}$

\section{A brief history of recent attempts at Lords reform}

The Labour government was elected in 1997 with a manifesto commitment to reform the House of Lords and, in 1999 a White Paper ${ }^{7}$ was issued in parallel with a Bill to remove the hereditary element from the House. Following a compromise known as the Weatherill amendment, a rump of 92 hereditaries remained under the subsequent House of Lords Act 1999 (pending the introduction of long-term reform). A year later the Royal Commission on House of Lords reform, which had been foreshadowed in the 1999 White Paper, issued its report in which it recommended a hybrid, largely appointed House. ${ }^{8}$ A further White Paper followed in $2001^{9}$ which, broadly, gave effect to the findings of the Royal Commission's recommendations and so proposed that one-fifth of the House be elected. Neither the report of the Royal Commission nor the 2001 White Paper proved to be particularly popular. In an effort to achieve some parliamentary consensus, a Joint Committee on House of Lords reform was established in July 2002. Its report set out a number of different options for a reformed composition, ranging from a wholly elected to a fully appointed chamber, with various hybrid positions in between. ${ }^{10}$ In 2003 both Houses of Parliament voted on these options and, although the House of Lords approved a fully appointed House, the House of Commons failed to endorse any (although it did reject the option of unicameralism). ${ }^{11}$ In the aftermath of this impasse, the government issued a consultation paper ${ }^{12}$ in September 2003 in which the lack of consensus on the introduction of an elected element was acknowledged. Instead, the government proposed to implement small-scale interim reforms, such as removing the remaining rump of hereditary peers. No legislation implementing these reforms, however, ever materialised.

In 2005 a non-governmental and cross-party group of MPs issued a document designed to show that broad agreement on Lords reform was possible. In essence, this report envisaged a hybrid House with up to 70 per cent being elected. ${ }^{13}$ Two years later the Labour government issued another White Paper ${ }^{14}$ prior to a second round of parliamentary votes taking place on the options considered in 2003. These votes proved to be rather inconclusive as, whereas the House of Lords voted overwhelmingly (though hardly

4 Albert Venn Dicey, 'Ought the Referendum to be Introduced into England?’ (1890) 57 Contemporary Review 489 and 'The Referendum and its Critics' (1910) 212 Quarterly Review 538.

5 Following David Butler and Austin Ranney (eds), Referendums around the World (Macmillan 1994) 1, in this paper the author will follow suit and use the plural of referendum to be referendums.

6 House of Lords Select Committee on the Constitution, Referendums in the United Kingdom HL Paper 99 (TSO 2010).

7 Modernising Parliament: Reforming the House of Lords Cm 4183 (TSO 1999). On the recent history of reform, see Meg Russell, The Contemporary House of Lords: Westminster Bicameralism Revived (OUP 2013) ch 10.

8 A House for the Future Cm 4534 (TSO 2000).

9 The House of Lords: Completing the Reform Cm 5291 (TSO 2001).

10 House of Lords Reform: First Report HL Paper 17, HC 171 (TSO 2002).

11 On these votes, see Mark Ryan, 'Parliament and the Joint Committee on House of Lords Reform' (2003) 37 Law Teacher 310. In addition, see Iain McLean, Arthur Spirling and Meg Russell, 'None of the Above: The UK House of Commons Votes on Reforming the House of Lords, February 2003' (2003) 74 Political Quarterly 298.

12 Constitutional Reform: Next Steps for the House of Lords CP 14/03 (DCA 2003).

13 Kenneth Clarke, Robin Cook, Paul Tyler, Tony Wright and George Young, Reforming the House of Lords: Breaking the Deadlock (Constitution Unit 2005) 43.

14 The House of Lords: Reform Cm 7027 (TSO 2007). 
surprisingly) in favour of a fully appointed House, the House of Commons by contrast approved the contradictory options of both a fully and an 80 per cent elected chamber. ${ }^{15}$ Thereafter, informed by this vote in the Commons (but not the Lords), the Labour government published a further White Paper in 2008 confining reform to either a wholly or an 80 per cent elected House. ${ }^{16}$ Although no major legislation was introduced, the end of the Labour administration's tenure did see it attempt to introduce smaller-scale interim reforms in the vehicle of the 2009-2010 Constitutional Reform and Governance Bill. These elements (e.g. resignation and suspension provisions) were, however, excised in April 2010 during the wash-up prior to the general election. ${ }^{17}$

At the general election of 2010, the issue of Lords reform formed part of all three of the main political parties' manifestoes. Whereas Labour ${ }^{18}$ and the Liberal Democrats ${ }^{19}$ advocated a fully elected chamber (albeit the former following a national referendum), the Conservatives $^{20}$ pledged to work towards a consensus on a mainly elected House. The Coalition government thereafter assumed power in May 2010 with a Coalition Agreement commitment (no doubt driven by the Liberal Democrat element of the administration) to create a committee to produce proposals on the reform of the House of Lords. ${ }^{21} \mathrm{~A}$ crossparty committee headed by the Deputy Prime Minister was immediately established, charged with producing draft reform proposals in the form of a parliamentary motion. One year later in May 2011, the Coalition government published a White Paper (albeit not a motion) which included a Draft House of Lords Reform Bill. ${ }^{22}$ In brief, the Draft Bill envisaged a House of 300 members of whom 80 per cent would be elected, although the White Paper made it clear that the Bill could be adapted to create a wholly elected House if required. Members would be elected in thirds by the single transferable vote system of proportional representation and the 20 per cent non-elected element would be appointed by a statutory Appointments Commission. ${ }^{23}$

The publication of the Draft Bill was followed by the establishment of the Joint Committee on the Draft House of Lords Reform Bill (hereafter the Joint Committee) to provide pre-legislative scrutiny of these proposals, and its report was published in late April 2012. ${ }^{24}$ Two months later, informed by this scrutiny, the fully fledged Bill (viz the House of Lords Reform Bill) received its first reading in the Commons. ${ }^{25}$ This Bill was similar to the draft that had preceded it except that one key difference was that the envisaged House had increased in size to 450 members (i.e. 360 elected and 90 appointed - cl 1(3)). A second

15 For an analysis of these votes, see Mark Ryan, 'A Consensus on the Reform of the House of Lords?' (2009) 60 NILQ 325.

16 An Elected Second Chamber: Further Reform of the House of Lords Cm 7438 (TSO 2008).

17 On the passage of this Bill, see Mark Ryan, 'The Constitutional Reform and Governance Act 2010: The Evolution and Development of a Constitutional Act' (2014) 35 Liverpool Law Review 233. It should be noted that one element on Lords reform concerning members of the House being deemed to be resident and domiciled in the UK for the purposes of tax, did survive the wash-up (s 41).

18 The Labour Party Manifesto 2010: A Future Fair for All (Labour Party 2010) 9.4.

19 Liberal Democrat Manifesto 2010: Change that Works for You (Liberal Democrats 2010) 88.

20 Invitation to Join the Government of Britain: The Conservative Manifesto 2010 (Conservative Party 2010) 67.

21 The Coalition: Our Programme for Government (Crown Copyright 2010) 27.

22 House of Lords Reform Draft Bill Cm 8077 (TSO 2011).

23 On the Draft Bill in general, see Mark Ryan, 'A Summary of the Developments in the Reform of the House of Lords since 2005' (2012) 21 Nottingham Law Journal 65.

24 Joint Committee on the Draft House of Lords Reform Bill (n 2).

25 HC Deb 27 June 2012, vol 547, col 308. 
major difference was the introduction of the semi-open list electoral system (Schedule 3). ${ }^{26}$ Although the Joint Committee had recommended a referendum, the Bill did not contain any provision for one. According to the Coalition government there did not 'seem to be a compelling case' to justify the expense that the staging of a referendum would incur. ${ }^{27}$

The House of Lords Reform Bill was considered by the House of Commons in July 2012 in a very lively two-day second reading debate and it is of interest to note that over 20 MPs spoke in favour of holding a referendum. ${ }^{28}$ The main principles of the Bill passed muster by the commanding margin of 462 to 124 votes. It was subsequently abandoned by the Coalition government, however, when it became clear that no programme motion (setting out the timetabling of the passage of the Bill) could be agreed by MPs. Although the side-lining of the House of Lords Reform Bill left long-term reform in abeyance, there still remained the possibility of implementing more modest reforms in the interim. In fact, in the preceding years, Lord Steel of Aikwood had on a number of occasions tried unsuccessfully to pilot a Private Member's Bill through Parliament which would have implemented a number of small-scale housekeeping reforms to the composition of the Lords. In 2013 Dan Byles MP incorporated some of these proposals in his Private Member's Bill: the House of Lords Reform Bill. This measure proved to be broadly consensual as it was designed to achieve three modest changes. It proposed to allow peers to resign, but also enable their expulsion for either non-attendance or following a serious criminal conviction. In May 2014 the Bill received the royal assent and, together with two other minor Acts passed the following year, ${ }^{29}$ represented the only reform of the House of Lords that would take place during the last Parliament. Any major reform of the House of Lords would accordingly have to wait until after the 2015 general election. At this election, both the Liberal Democrat ${ }^{30}$ and the Labour parties 31 manifestoes pledged to introduce an elected second chamber. Although the newly elected Conservative government's manifesto recognised the case for an elected Lords, it was not regarded as a priority for the incoming Parliament. ${ }^{32}$ It is plain, therefore, that no long-term reform will be undertaken during the current Parliament.

26 This was the system proposed for Great Britain; however, under $\mathrm{cl} 5(5)$ of the Bill it was envisaged that for historical reasons Northern Ireland would use the single transferable vote.

27 Government Response to the Report of the Joint Committee on the Draft House of Lords Reform Bill (n 3).

28 For example, on the first day of the second reading the following, among others, supported a referendum on these proposals: HC Deb 9 July 2012, vol 548, Sadiq Khan (col 45); Alan Johnson (col 58); Rory Stewart (col 36); Eleanor Laing (col 58) and Graham Brady (col 63). On the Bill in general, see Mark Ryan, 'The Latest Attempt at Reform of the House of Lords: One Step Forward and Another One Back' (2013) 22 Nottingham Law Journal 1.

29 On the House of Lords Reform Act, see Mark Ryan, 'Bills of Steel: The House of Lords Reform Act 2014' [2015] Public Law 558. The other two measures were the House of Lords (Expulsion and Suspension) Act 2015, which provided for the expulsion and suspension of members, and the Lords Spiritual (Women) Act 2015 which provided for the acceleration of female bishops to sit in the House of Lords.

30 Manifesto 2015: Strong Economy. Fair Society. Opportunity for Everyone (Liberal Democrats 2015) 132.

31 Britain Can Be Better: Labour Party Manifesto 2015 (Labour Party 2015) 64, although it did support a Constitutional Convention to drive forward Westminster reform. It is interesting to note that in March 2014 a Labour Peers' Working Group recommended that any major reform of the second chamber be implemented only if approved by the people in a referendum: A Programme for Progress: The Future of the House of Lords and its Place in a Wider Constitution (Labour Peers' Working Group 2014) 32.

32 The Conservative Party Manifesto 2015 (Conservative Party 2015) 48. 


\section{The referendum and the British Constitution}

Outside of the UK, constitutional laws are invariably accorded a higher legally entrenched special status to reflect their fundamental character as principles which underpin the basic framework of the state. As a consequence, changes to a codified constitution are subject to a procedure prescribed by the constitutional document. Such procedures could involve a legislative supermajority (Germany), two readings of the measure in successive parliaments (Netherlands) or endorsement of the reform in a referendum (Republic of Ireland). A constitutional referendum can be either mandatory, whereby the constitution stipulates that any amendment to the constitution is to be ratified by the people (Republic of Ireland: Article 46), or optional in which a referendum is one way of altering the constitution (France: Article 89). In general terms, therefore, a referendum can be seen 'as a weapon of entrenchment ${ }^{\prime 3}$ whereby an obstacle (i.e. the people as the constituent power) can protect the constitution from changes which it considers undesirable. The last three decades have witnessed a surge in the use of referendums on the international plane, ${ }^{34}$ with referendums being used increasingly to resolve constitutional questions of a fundamental nature. ${ }^{35}$ In fact, Professor Tierney has suggested that 'the task for the constitutional scholar today is to engage with how deliberative democracy might be fostered within constitutional referendums [sic]'.36

In contrast to elsewhere, the defining characteristic of the British Constitution is the legislative supremacy of Parliament (hereafter parliamentary sovereignty as used by Professor Dicey). This doctrine fills the void left by the historical absence of a codified constitutional document. It has the consequence that our constitutional laws are comparatively flexible and open to change by virtue of the passage of a simple Act of Parliament. Following a general election, parliamentary members enact laws on the basis of a mandate supplied by the people and there is a clear 'division of labour' between the government and the governed. ${ }^{37}$ In short, the public are not involved in the post-election legislative process, whether for constitutional or non-constitutional laws. This is because representative government does not give an institutional role to the people. ${ }^{38}$ The paradox of parliamentary representation, therefore, is that it both includes the people (albeit infrequently through elections), but also 'simultaneously, it serves to exclude them from direct and continuous participation in the decision-making process' ${ }^{39}$

In Britain the referendum, historically, has been regarded as alien to our traditions ${ }^{40}$ and unconstitutional. ${ }^{41}$ Direct democracy has been viewed as undermining parliamentary sovereignty and representative democracy ${ }^{42}$ because it could result in rejecting a decision made by elected parliamentarians. In a referendum the people replace their parliamentary

33 Vernon Bogdanor, The People and the Party System (CUP 1981) 69.

34 Stephen Tierney, 'Constitutional Referendums: A Theoretical Enquiry' (2009) 72(3) Modern Law Review 360.

35 Stephen Tierney, Constitutional Referendums (OUP 2012) 1.

36 Ibid 303.

37 See further, Geraint Parry, George Moyser and Neil Day, Political Participation and Democracy in Britain (CUP 1992) 5.

38 Bernard Manin, The Principles of Representative Government (CUP 1997) 8.

39 David Judge, 'Whatever Happened to Parliamentary Democracy in the United Kingdom?' (2004) 57 Parliamentary Affairs 683.

40 Described as such by Clement Attlee in 1945 and quoted in Philip Goodhart, Referendum (Tom Stacey Ltd, 1977) 49.

41 Report of the Commission on the Conduct of Referendums (Electoral Reform Society and the Constitution Unit 1996) 6.

42 As recorded in the evidence supplied to the House of Lords Select Committee on the Constitution (n 6) 20. 
representatives who, according to the historic Burkean precept, ${ }^{43}$ have been entrusted with the responsibility to make decisions in Parliament. Such decisions are made in accordance with an MP's experience, judgment and ability to assess an issue in its broad overall context (rather than in the vacuum of an isolated referendum). It has been noted that representative institutions therefore 'create the conditions for a more deliberative approach to decisionmaking. ${ }^{44}$ It has also been argued that referendums undermine the principle of accountable government which requires the administration to be constitutionally responsible for policy decisions and held to account thereafter by the people. ${ }^{45}$ Professor Tierney has posited that constitutional referendums (unlike ordinary/legislative referendums which 'do not impact upon the location and distribution of sovereign power within the state') ${ }^{46}$ raise distinct challenges to the understanding of supremacy in the context of a representative governmental system.

Although the traditional view has been that direct democracy is incongruous with the British Constitution, it must be recalled that Professor Dicey (the person most closely associated with the principle of parliamentary sovereignty) actually approved of selective referendums as they gave expression to the people's will. ${ }^{47} \mathrm{He}$ recognised the practical reality that the elected assembly of MPs could fail to represent the people/nation with guillotine and closure motions destroying free rational debate and party political discipline undermining the independence of members. 48 Professor Dicey viewed the referendum as an essentially negative device (a 'bridle'). ${ }^{49}$ It could counterbalance a temporary party political majority which wanted to make constitutional changes without the direct sanction of the public. ${ }^{50}$ In particular, he was vigorously opposed to the passage of Home Rule legislation for Ireland which he believed the electorate opposed. ${ }^{51}$ It has certainly not gone unnoticed that the Crown in Parliament has absorbed the constituent power in the UK and that Parliament 'has usurped the role of "the people" in the constitutional imagination'.52 On one view, therefore, the mechanism of the referendum could be regarded as 'a necessary complement to representative democracy, which fails to recognise the advent of party government and the influence of organised interest groups'. ${ }^{53}$ In fact, it has been pointed out that the referendum does not represent an attack on representative government, but instead it is incompatible 'with an over rigid party system'. 54

According to Professor Bogdanor, the effect of a referendum is to divide legislative power between the people and the legislature (thereby checking the executive), with the

43 On Burke's famous address, see Jesse Norman, Edmund Burke (William Collins 2014) 77-8.

44 Tierney (n 35) 28.

45 As noted by the Report of the Commission on the Conduct of Referendums (n 41) 23.

46 Tierney (n 34) 364.

47 Dicey, 'The Referendum and its Critics' (n 4) 551.

48 Ibid 540-1.

49 Ibid 543.

50 Dicey, 'Ought the Referendum to be Introduced into England?' (n 4) 506.

51 Dicey, 'The Referendum and its Critics' (n 4) 540. On Dicey and Home Rule, see Richard Cosgrove, The Rule of Law: Albert Venn Dicey, Victorian Jurist (Macmillan 1980) 105.

52 Martin Loughlin, 'Constituent Power Subverted: From English Constitutional Argument to British Constitutional Practice' in Martin Loughlin and Neil Walker (eds), The Paradox of Constitutionalism (OUP 2008) 27-8.

53 Mads Qvortrup, A Comparative Study of Referendums (Manchester University Press 2002) 7.

54 Bogdanor (n 33) 81. 
people in effect becoming 'a third chamber'55 (or acting as a 'Third Reading'). ${ }^{56}$ Professor Norton has also noted that a referendum divides the legislative and executive functions, preventing the government from controlling the former. ${ }^{57}$ Direct democracy, therefore, provides an obstacle to change in a state - such as the UK - which lacks a codified constitution. ${ }^{58}$ Professor Dicey argued that a referendum would be the veto of the nation ${ }^{59}$ and it was democratic precisely because it protected the people's sovereignty. ${ }^{60}$ For Professor Bogdanor, the referendum performs an entrenching role in a state lacking a rigid codified constitution. ${ }^{61}$ It should be remembered though that a referendum can only take place in the UK with express legislative authority. Indeed, as 'referendums cannot be legally binding' ${ }^{62}$ (and so remain advisory), sovereignty is retained, although of course it would be difficult politically for Parliament to ignore an outcome with which it disagreed. The result of a referendum could, therefore, become de facto politically mandatory.

The referendum is, however, hardly an unknown device in the UK. In recent decades our ever-changing constitution has adapted to embrace both UK-wide and regional referendums in order to determine specific constitutional issues. There have been two UKwide referendums (197563 and 2011), ${ }^{64}$ together with a number of regional ones, which exhibit a policy of using referendums prior to the implementation of devolution/decentralisation in Scotland (1979 and 1997), ${ }^{65}$ Wales (1979, 1997), ${ }^{66}$ London (1998), ${ }^{67}$ Northern Ireland (1998) ${ }^{68}$ and the North East (2004). ${ }^{69}$ Northern Ireland also had a border poll in $1973^{70}$ and, very recently in September 2014, Scotland rejected independence in a referendum held under the Scottish Independence Referendum Act 2013. Professor Bogdanor had observed in 1996 that the constitution knew nothing of the British people. ${ }^{71}$ Fifteen years later, however, following the constitutional reform programme commenced in 1997 (elements of which had been validated by a referendum), he commented 'that the people have become, at last, a part of the British constitution'. ${ }^{72}$

55 Vernon Bogdanor, 'Western Europe' in Butler and Ranney (n 5) 30.

56 Bogdanor (n 33) 69.

57 Norton (n 1) 218.

58 Bogdanor (n 55) 46.

59 Dicey, 'The Referendum and its Critics' (n 4) 559.

60 Dicey, 'Ought the Referendum to be Introduced into England?' (n 4) 507.

61 Bogdanor (n 33) 71.

62 House of Lords Select Committee on the Constitution (n 6) 46. In this context, also see Rodney Brazier, Constitutional Reform (3rd edn OUP 2008) 23.

63 Referendum Act 1975.

64 Parliamentary Voting System and Constituencies Act 2011.

65 The Scotland Act 1978 and Referendums (Scotland and Wales) Act 1997, respectively.

66 The Wales Act 1978 and Referendums (Scotland and Wales) Act 1997, respectively. More recently a referendum took place in Wales in 2011 on extending the legislative powers of the Welsh Assembly, thereby demonstrating the 'rolling process' of devolution. The referendum was held under the aegis of ss 103-4 of the Government of Wales Act 2006 and the National Assembly for Wales Referendum (Assembly Act Provisions) (Referendum Question, Date of Referendum Etc.) Order 2010 SI 2010/2837.

67 Greater London Authority (Referendum) Act 1998.

68 Northern Ireland Negotiations (Referendum) Order 1998 SI 1998/1126.

69 Regional Assemblies (Preparations) Act 2003.

70 Northern Ireland (Border Poll) Act 1972.

71 Vernon Bogdanor, Politics and the Constitution (Dartmouth 1996) 213.

72 Vernon Bogdanor, 'An Era of Constitutional Reform' (2011) Political Quarterly 55. 
At a local level, referendums are more established in Britain. ${ }^{73}$ For example, provision is made for local referendums/polls under the aegis of the Local Government Act 1972 (Schedule 12, para 18(4) - parish polls), Local Government Act 2003 (s 116 - polls on services etc.) and under the Local Government Act 2000 (as amended ${ }^{74}$ - prior to the establishment of elected mayors). Section 72 of the Localism Act 2011 also provides for mandatory local referendums on proposed excessive council tax increases. In terms of the EU, pt 1 of the European Union Act 2011 provides for a UK-wide referendum in the event of a treaty change or decision that proposed to transfer competence or power from the UK to Europe. More recently, at the time of writing, the newly elected Conservative government was piloting the 2015 European Union Referendum Bill through Parliament which stipulated that a referendum must be held before the end of 2017 on whether the UK should remain a member of the EU. In the event that this Bill becomes law, this referendum would be the second referendum in relation to our membership of Europe, some four decades after the UK's very first UK-wide referendum.

Such has been the increasing prominence of domestic referendums in recent years that in 2009 the House of Lords Select Committee on the Constitution (hereafter the Select Committee) was moved to investigate the role of referendums in the UK. It concluded that if referendums were to be used in the UK then 'they are most appropriately used in relation to fundamental constitutional issues' (emphasis added). ${ }^{75}$ In fact, it has been recorded that on the international plane the majority of referendums have focused on constitutional issues. ${ }^{76} \mathrm{It}$ has to be said that the concept of a British referendum on constitutional issues already has some weighty provenance. In 1890 Professor Dicey floated one proposal that no legislation which would affect, inter alia, the constitution of either parliamentary chamber should have effect or come into force until sanctioned by the electors. ${ }^{77}$

\section{A seminal constitutional change}

The first argument that the Coalition government should have acceded to the Joint Committee's recommendation in 2012 for a referendum was that it was necessary because the envisaged change in composition to a largely elected House would have had a profound effect on our uncodified constitutional arrangements. At the outset, the view of the Select Committee in 2010 on this issue should be recorded. Although the Select Committee conceded that it was not possible to give an exact definition as to what 'a "fundamental constitutional issue" "was, it nevertheless listed the matters which it considered fell within and so deemed appropriate - for a referendum. ${ }^{78}$ These included the abolition of the House of Lords, but did not include changing the composition of the second chamber. Even though the Select Committee indicated that its list was not meant to be definitive, its then chair, Baroness Jay of Paddington, in explaining the content of the report to the

73 Matt Qvortrup, 'Democracy by Delegation: The Decision to Hold Referendums in the United Kingdom' (2006) 42 Representation 60. On local authorities and polls, see Mark Sandford, Local Government: Polls and Referendums (House of Commons Library 2014).

74 The Local Government and Public Involvement in Health Act 2007 and the Localism Act 2011.

75 House of Lords Select Committee on the Constitution (n 6) 27.

76 Report of the Commission on the Conduct of Referendums (n 41) 22. According to Lawrence Le Duc, the most common issues of referendums held in 58 democratic countries between 1975-2000 were the following: constitutional issues; international treaties and agreements; matters of national sovereignty/selfdetermination; and other issues of public policy (The Politics of Direct Democracy (Broadview Press 2003) 34, table 1.1).

77 Dicey, 'Ought the Referendum to be Introduced into England?' (n 4$) 499$.

78 House of Lords Select Committee on the Constitution (n 6) 27. 
House of Lords, drew specific attention to the fact that the Select Committee had not included Lords reform 'as a fundamental constitutional issue'. ${ }^{79}$

One could nonetheless take issue with this finding of the Select Committee. In short, it is contended that any proposal to transform the composition of the House of Lords from an appointed chamber to an elected one would be a fundamental constitutional change (and so would warrant a referendum). It would clearly not be a secondary or minor constitutional reform as it would be 'one of the most significant constitutional changes in a century'. ${ }^{80}$ As constitutional reform cannot be forged in a vacuum, the reform of the second chamber would have secondary effects reverberating elsewhere. In particular, the advent of an elected second chamber would have a profound impact on the constitutional relationship between the two Houses and the real dynamic of the British Constitution: viz, executive/parliamentary relations. It is posited that a reformed chamber armed with an electoral mandate would be likely to be more robust in its dealings with both the lower House and the government of the day. ${ }^{81}$ After all, such a chamber would undoubtedly feel more constitutionally legitimate by virtue of being elected. In fact, a more legitimate House of Lords was the raison d' etre of the Coalition government's proposals for reform. ${ }^{82}$ It is germane that research has revealed that, following the removal in 1999 of most of the hereditary peers (the most constitutionally controversial element of the chamber), the legitimacy of the House of Lords was boosted, which made it more confident in its dealings with the executive. ${ }^{83}$

Although the Parliament Acts of 1911 and 1949 determine the legal relationship between the two Houses and preserve the legal primacy of the Commons, a newly elected chamber would be much more assertive than the House of Lords is at present. It is possible that it would use its legal powers under the Parliament Acts (which are still 'relatively great in comparative terms') 84 to the full. It is only by convention that the current House of Lords exercises self-restraint and, in fact, the Coalition government accepted that an elected House of Lords was likely to be more assertive. ${ }^{85} \mathrm{~A}$ majority of the Joint Committee believed that, despite the shift in the balance of power between the two Houses that would ensue following reform, 'the remaining pillars' (i.e. the Parliament Acts etc.) would be sufficient to ensure the continuation of the Commons' primacy. ${ }^{86} \mathrm{~A}$ minority of the Joint Committee argued in a separate Alternative Report, however, that there was an incompatibility and 'an unbridgeable gap' between an elected upper House and the maintenance of primacy. In short, the government's proposals had put the primacy of the Commons 'into play'. ${ }^{87}$

79 HL Deb 12 October 2010, vol 721, col 409.

80 Lord Dobbs, HL Deb 30 April 2012, vol 736, col 2057.

81 As the Bill proposed a form of proportional representation, it would appear unlikely that one party (including the government) would be able to dominate the second chamber.

82 House of Lords Reform Draft Bill (n 22) 29.

83 Meg Russell and Maria Sciara, 'The House of Lords in 2006: Negotiating a Stronger Second Chamber' (Constitution Unit 2007). In this context, also see, Meg Russell and Maria Sciara, 'The Policy Impact of Defeats in the House of Lords' (2008) 10 British Journal of Politics and International Relations 571.

84 Meg Russell, 'Judging the White Paper against International Practice of Bicameralism' in Alexandra Fitzpatrick (ed), The End of the Peer Show? (CentreForum 2011) 25.

85 Government Response to the Report of the Joint Committee on the Draft House of Lords Reform Bill (n 3$) 6$.

86 Joint Committee on the Draft House of Lords Reform Bill (n 2) 20.

87 Alternative Report, House of Lords Reform: An Alternative Way Forward <www.houseoflordsrefrom.com>39-40. 
It should also be remembered that the existing conventions which have ensured collaborative inter-House relations have been predicated on the acceptance that the Commons is the elected House. It is not difficult, however, to imagine newly elected members withdrawing their co-operation in day-to-day parliamentary business and discarding (or at the very least questioning) the present conventions which regulate relations with both the Commons and the government of the day. For example, would - or even should - one of these conventions, such as the Salisbury-Addison convention (which provides that the House of Lords should accord a second reading to a government Bill foreshadowed in its manifesto) apply in the context of both Houses being elected?

The Joint Committee on Conventions in its 2006 report made the point that its conclusions in relation to these conventions would have to be revisited in the event that the composition of the second chamber changed (i.e. acquired an electoral mandate). ${ }^{88}$ In May 2011, the Political and Constitutional Reform Select Committee asserted that these conventions would not survive in their present form if the upper House had 'democratic legitimacy'. ${ }^{89}$ The Joint Committee on the Draft Bill also recognised that in a reformed House of Lords these conventions would evolve and recommended that work should begin promulgating them (together with any new ones) by way of a 'concordat' to be agreed through parallel resolutions in both chambers. ${ }^{90}$ For its part, although the Coalition government conceded that the existing conventions would evolve, it did not agree that work now needed to begin 'to establish new or developed conventions, or dispute resolution procedures'. ${ }^{91}$ In the final analysis, the Joint Committee reported that 'By any standard, the Government's proposal to reform the House of Lords is of major constitutional significance ${ }^{92}$ and accordingly recommended that a referendum take place. ${ }^{93}$ In fact, the minority Alternative Report argued that changes to the second chamber 'not only should not be done without a referendum but in practice could not be done without a referendum' (emphasis added). ${ }^{94}$

The reform of the House of Lords would undoubtedly be a seminal constitutional reform. It has been pointed out that in a representative democracy (in general) the people's representatives should not assume that they have the right to determine the terms on which they hold political office or the powers that they exercise. In other words, these 'are prior questions which properly belong in a written constitution, subject to the approval of the people'. 95 Professor Tierney, furthermore, has theorised that at the 'sovereignty decisionmaking' level (i.e. issues in which the nature of the state is redefined fundamentally, such as a cardinal change to Parliament's nature), it may be that some (albeit limited) room should be available for the use of referendums. In short, at this level:

the issues are so fundamental that people should be able to reclaim their direct constitutional authority; and secondly, that these decisions involve the very identity of a sovereign people and again, therefore, that people should be able to play a direct role in such an exercise of constitutional 'self-definition'. 96

88 Joint Committee on Conventions, Conventions of the UK Parliament HL Paper 265-I, HC 1212-I (TSO 2006$) 3$.

89 Political and Constitutional Reform Committee, Seminar on the House of Lords: Outcomes HC 961 (TSO 2011$) 5$.

90 Joint Committee on the Draft House of Lords Reform Bill (n 2) 26.

91 Government Response to the Report of the Joint Committee on the Draft House of Lords Reform Bill (n 3 ) 8.

92 Joint Committee on the Draft House of Lords Reform Bill (n 2) 92.

93 Ibid 96.

94 Alternative Report (n 87) 76.

95 Stuart Weir and David Beetham, Political Power and Democratic Control in Britain (Routledge 1999) 111.

96 'Memorandum', House of Lords Select Committee on the Constitution (n 6) 49. 
It is contended therefore that the proposal in 2012 (or indeed any such plans in the future) to replace the appointed composition of the House of Lords with elected members fell squarely within Professor Tierney's parameters of a fundamental redefinition of the state. An elected House would have transformed the way in which the constituent power was represented and reflected in the legislature and therefore warranted a referendum. In this context it is fascinating to recall that a clause was moved (albeit unsuccessfully) by the Conservative opposition in May 1911 in respect of the Parliament Bill. This provision stipulated that any Bill which, inter alia, altered the constitution, powers or relations between the two Houses, could not be presented for royal assent until it had been submitted to a poll of the electorate and approved by them. ${ }^{97}$

Finally, as an aside, although the Select Committee identified the abolition of the House of Lords as an issue appropriate for a referendum, it is pertinent to note that, for some, the replacement of the chamber's composition with elected members would in practice amount to the de facto abolition of the House of Lords. ${ }^{98}$ It is fair to argue though that this 'abolition' would not have been immediate under the 2012 House of Lords Reform Bill, as it would have involved a 10-year transitional period commencing in May 2015 (cll 1 and 3). It is somewhat coincidental that three months after the Commons had considered the House of Lords Reform Bill, a proposal to abolish Ireland's upper House (the Senate) was rejected by the Irish people in a national referendum. This was an issue, of course, on which the 2010 Select Committee would have recommended a referendum on in the UK.

\section{A constitutional precedent?}

A second argument for a referendum was that a precedent had been laid down with the events of May 2011. In the UK there is no general Referendum Act which stipulates the circumstances as to when a nationwide referendum should be triggered. Although in strict legal theory the decision to hold a referendum is one for Parliament, the political reality is that this matter is decided by the government of the day. It is certainly the case that both of the UK-wide referendums which have been held to date have been 'controlled' 99 (i.e. determined by the incumbent government). For example, the 1975 referendum was driven by the desire for unity by the then Labour Party/government's internal division over the issue of Europe. ${ }^{100}$ In fact, the Select Committee regretted in general 'the ad hoc manner in which referendums have been used, often as a tactical device, by the government of the day'. ${ }^{101}$ It is pertinent to note that the referendum scheduled to take place before the end of 2017 on the UK's continued membership of the EU had been foreshadowed in the Conservative Party's 2015 general election manifesto. ${ }^{102}$

In the absence of any general Referendum Act, it can nevertheless be argued that a constitutional precedent for a referendum on Lords reform was set by the Parliamentary Voting System and Constituencies Act 2011. Section 1 enabled a UK-wide referendum to take place in May 2011 on whether the existing electoral system to elect MPs should be replaced with the alternative vote (in the event, something which the public rejected

97 Goodhart (n 40) 37. See HC Deb 8 May 1911, vol 25, col $915 \mathrm{ff}$.

98 Lord Grenfell, HL Deb 11 October 2010, vol 721, col 344.

99 Using the terminology cited in Arend Lijphart, Democracies (Yale University Press 1984) 203 - Lijphart has argued that 'Most referendums are both controlled and pro-hegemonic' (i.e. they are determined by the government and the result of the referendum is supportive of that administration), cf. Mads Qvortrup, 'Are Referendums Controlled and Pro-hegemonic?' (2000) 48 Political Studies 821.

100 Norton (n 1) 214 and Vernon Bogdanor, Power and the People (Victor Gollancz 1997) 125.

101 House of Lords Select Committee on the Constitution (n 6) 20.

102 Conservative Party Manifesto 2015 (n 32) 30. 
decisively). ${ }^{103}$ This surely then begged the question that if it could be argued that a possible change in the electoral system for the House of Commons from one majoritarian system to another was important enough to justify a referendum, why then was not the decision to introduce the principle of elections into the upper House also worthy of a referendum?

It is noteworthy that the Select Committee drew attention to the previous Labour government's inconsistency in advocating a referendum on the alternative vote, ${ }^{104}$ but not one on reforming the composition of the Lords. ${ }^{105}$ What is curious is that, as noted, the Select Committee itself declined to include the reform of the Lords (other than its abolition) as a fundamental constitutional issue meriting a referendum. The then Labour government conceded that, although Lords reform was 'a fundamental constitutional change it is a change that will have been pre-figured in a manifesto commitment, in fact in several manifesto commitments'. ${ }^{106}$ More recently, the Coalition government's Deputy Prime Minister also justified not having a referendum on Lords reform on the basis that, unlike in relation to a change in the electoral system, all three parties had agreed to reform the second chamber in their 2010 manifestoes. ${ }^{107}$ This explanation was far from convincing. Although the issue of the 2010 manifestoes will be dealt with below, suffice to say at this point that the commitments on Lords reform by the main political parties were not identical. Furthermore, the 2012 House of Lords Reform Bill actually contradicted the 2010 Liberal Democrat manifesto commitment for a wholly elected House. It is also often forgotten that no political party actually won the 2010 general election and that in any case, the Labour Party had proposed a referendum.

In short, it appeared inconsistent from a constitutional perspective to hold a referendum on changing the electoral system for the House of Commons, but not to hold one to introduce the principle of elections into the second chamber. It could be contended that once the principle of having a referendum to settle a constitutional issue is conceded, it is difficult, at least politically, to prevent it from being invoked again in relation to other (and arguably more significant) constitutional issues such as reforming the House of Lords. Indeed, the minority Alternative Report argued that the precedent of the 2011 referendum suggested that it would be unwise for governments 'to try to proceed with major national constitutional change without having first sought the direct mandate of the electorate in a referendum'. ${ }^{108}$ Finally, it does seem that there is now a developing view/convention as to when referendums should take place. During the second reading of the House of Lords Reform Bill, Sadiq Khan MP (the then Shadow Secretary of State for Justice) regretted the government's dismissal of a referendum and asserted that there was now a 'growing tradition that major constitutional change should be put to the people in a referendum'. ${ }^{109}$ More recently, in July 2014 the Political and Constitutional Reform Committee commented that there were now precedents which may amount to a convention or doctrine as to when referendums should be held and that these included 'when a wholly novel constitutional arrangement is proposed'. ${ }^{110}$ It is contended that any proposal to create an elected second chamber would clearly represent such a novel arrangement in our constitutional framework.

103 Referendum on the Voting System for UK Parliamentary Elections (Electoral Commission 2011) 5.

104 As inserted in the Constitutional Reform and Governance Bill at the committee stage in the House of Commons. However, this referendum element was subsequently removed in the wash-up in April 2010.

105 House of Lords Select Committee on the Constitution (n 6) 26.

106 Ibid Q 220, the Minister of State at the Ministry of Justice, Michael Wills MP.

107 Nick Clegg, HC Deb 27 June 2011, vol 530, col 649.

108 Alternative Report (n 87) 76.

109 HC Deb 9 July 2012, vol 548, col 45.

110 A New Magna Carta? HC 463 (TSO 2014) 394. 


\section{Avoiding an insular parliamentary perspective on Lords reform}

The third argument in favour of a referendum was that it would have avoided an introspective parliamentary approach to this fundamental constitutional issue. Constitutional reform in general in the UK has been far too parliamentary-centric and introspective without any real reference to engaging the wider public'. ${ }^{111}$ 'This insular attitude has been a hallmark which, unfortunately, has characterised the debate on Lords reform in recent years (i.e. the 2003 and 2007 parliamentary votes were essentially exclusive parliamentary affairs with no real reference to the wider public). It is a constitutional maxim that the British Constitution - or its reform - is not the preserve of any one political party, but neither is it the exclusive preserve of parliamentarians (and, more specifically, MPs). It has also not gone unnoticed that as both the government of the day and MPs have a vested interest in constitutional changes, any such alterations arguably should require endorsement by the public. ${ }^{112}$ In recent years great play has been made of the disconnection between the public and Parliament and how this relationship can be engendered. ${ }^{113}$ As an aside, Professor Tierney has suggested that one reason for the increase in the use of referendums on the international plane may be due to increasing public dissatisfaction with representative and conventional politics. ${ }^{114}$ In July 2010, the Deputy Prime Minister stated that the Coalition government's 'ambitious programme for political renewal' would involve, inter alia, empowering people by transferring power away from Parliament. ${ }^{115}$ This was followed up by the government in its official response to the Select Committee which stated that: "We are firmly committed to giving people a greater say in politics and we believe that referendums can be one means of achieving this.'116

As observed by the Select Committee, one advantage levelled in favour of referendums is that they can engage the citizen with the political process ${ }^{117}$ and thereby serve the principle of participatory government. Although participation in public affairs is clearly an inherently recognisable good and so 'valued for its own sake,, 118 our uncodified constitutional arrangements allow changes to the basic framework of the state to be made without any reference to the people at all. It is certainly the case that the Joint Committee's call for evidence in 2011 was hardly a substitute for ascertaining a comprehensive view of the public on the issue of Lords reform in a single-issue referendum. On a general/international level, it has been noted that there is 'a sense that there is a need to reengage the demos directly with democracy'. ${ }^{119}$ Moreover, constitutional referendums 'can lead to a heightened level of interest by citizens'. ${ }^{120}$ Although the turnout of 42 per cent at

111 Written evidence of Mark Ryan, quoted in the Joint Committee on the Draft House of Lords Reform Bill (n 2) 94.

112 Katy Donnelly and Nicole Smith, 'Implementing Constitutional Reform' in Robert Blackburn and Raymond Plant (eds), Constitutional Reform (Longman 1999) 216.

113 For example, see the Select Committee on Modernisation of the House of Commons, Connecting Parliament with the Public HC 368 (TSO 2004). In addition, one of the principles which underpinned the 2007 Green Paper was to re-invigorate British democracy: The Governance of Britain Cm 7170 (Crown Copyright 2007) 40. More recently, in July 2014 the report of the House of Commons Political and Constitutional Reform Committee (n 110) attempted to connect directly with, and engage, the public.

114 Tierney (n 35) 9.

115 HC Deb 5 July 2010, vol 513, col 23.

116 Mark Harper MP, Parliamentary Secretary, Cabinet Office, Government Response to the Report on Referendums in the United Kingdom: Report HL Paper 34 (TSO 2010) 4.

117 House of Lords Select Committee on the Constitution (n 6) 14.

118 Barry Holden, The Nature of Democracy (Nelson 1974) 70.

119 Tierney (n 35) 44.

120 Ibid 36. 
the May 2011 referendum ${ }^{121}$ was disappointing, survey data from 2011 nevertheless indicated that referendums in general are popular with the British public. ${ }^{122}$ Indeed, the recent referendum on Scottish independence generated considerable interest both north and south of the border, with a turnout registering 85 per cent. ${ }^{123}$

As recorded by the Select Committee, another advantage of referendums is that they can confer legitimacy ${ }^{124}$ on any reform approved by the people. It has been commented that in the late 1990s the referendums in Scotland and Northern Ireland conferred more legitimacy on the devolution of power than (arguably) if this had been carried out by politicians simply acting alone. ${ }^{125}$ Professor Tierney has remarked that 'the referendum can be seen as "pure democracy". In other words democracy unmediated by representatives; a symbolic reminder that democratic authority finds its legitimacy in the consent of the people.' 126 It has been argued that the case for a referendum is that it maximises legitimacy as it is 'the most authoritative' expression of the popular/public will in contrast to the rather indirect expression provided through the conduit of parliamentary representatives. ${ }^{127}$ Professor Loughlin has noted that the constituent power helps us to 'locate the source of modern political authority' and that it 'articulates the power of the multitude: constituent power is the juristic expression of the democratic impetus. The concept expresses the tensions between democracy and law'. ${ }^{128}$ Moreover, it is in this context of the so-called 'paradox of constitutionalism', 129 that Professor Lindahl referred to the 'moves to recover the primacy of constituent power over constituted power, and of democracy over the rule of law'. ${ }^{130}$ It is contended accordingly that the seminal constitutional changes which would have flowed from the introduction of elected members to the second chamber, would have been so profoundly constitutionally significant that they would have warranted express approval - and legitimisation - by the constituent power. The Joint Committee quite wisely drew attention to the fact that without a referendum, the people would have had no opportunity to approve the changes set out in the 2012 House of Lords Reform Bill before they voted in the first elections to the reformed chamber scheduled for May 2015. ${ }^{131}$

One argument levelled against direct democracy is that it leaves decision-making to those lacking informed opinion. ${ }^{132}$ In other words, the public lack the requisite expertise and knowledge to appreciate the constitutional nuances and implications that would ensue from a change in the composition of the upper House. Professor Budge noted that two centuries ago the American political theorist (and later President) James Madison saw representatives as acting as a 'filter' for public/popular opinion. ${ }^{133}$ Today such a view would

121 Colin Rallings and Michael Thrasher (eds), British Electoral Facts 1832-2012 (Biteback Publishing 2012$) 243$.

122 John Curtice and Ben Seyd, Will the Coalition's Constitutional Reforms Re-engage a Sceptical Electorate? British Social Attitudes 29 (NatCen 19 April 2012) table 2: 'How should decisions be made?'.

123 Roderick McInnes, Steven Ayers and Oliver Hawkins, Scottish Independence Referendum 2014 (House of Commons Library 2014) 13.

124 House of Lords Select Committee on the Constitution (n 6) 13.

125 Qvortrup (n 53) 121.

126 'Memorandum', House of Lords Select Committee on the Constitution (n 6) 48.

127 Butler and Ranney (n 5) 14-15.

128 Martin Loughlin, The Idea of Public Law (OUP 2003) 99-100.

129 Martin Loughlin and Neil Walker (eds), The Paradox of Constitutionalism (OUP 2007) 1.

130 Hans Lindahl, 'Constituent Power and Reflexive Identity: Towards an Ontology of Collective Selfhood' in ibid 9 .

131 Joint Committee on the Draft House of Lords Reform Bill (n 2) 93.

132 As noted by Sara Binzer Hobolt, Europe in Question (OUP 2009) 6.

133 Ian Budge, The New Challenge of Direct Democracy (Blackwell 1996) 73. 
do a disservice to the public who would be educated by the comprehensive debate which would accompany any referendum (as publicised by the Electoral Commission). Professor Brazier has stressed that the modern public are better educated than in Edmund Burke's day and that they can be expected to make intelligent decisions provided adequate information is supplied. ${ }^{134}$ Indeed, in a 2011 survey, 73 per cent of people stated that they had had sufficient information to make an informed decision in relation to the referendum on the alternative vote. ${ }^{135} \mathrm{It}$ is self-evident, therefore, that the staging of a referendum would have an educative effect. Professor Tierney has commented that, when an issue of fundamental constitutional importance is at stake, the less compelling might be the argument that people lack the capacity to engage with politics in these exceptional moments of great significance'. ${ }^{136}$ In any case, if the argument that the public lack sophistication in constitutional/political matters has any currency, then there was clearly no case for a referendum to take place on the alternative vote, or further, to even propose that people vote in elections to a reformed second chamber (the raison d' etre of the 2012 House of Lords Reform Bill). As Professor Budge has observed, it is very difficult to stop arguments against direct democracy developing into arguments against democracy itself'. ${ }^{137}$

It could be argued that a referendum on the reform of the House of Lords was superfluous as we already knew what the view of the public was from surveys which have (historically) indicated support for an elected upper House. In his oral evidence to the Select Committee, the then Labour Minister, Michael Wills MP asserted that, if a referendum were to be held, 'without any doubt, I think, we would win the referendum on the case for a wholly or partly-elected House of Lords' ${ }^{138}$ It is argued, however, that the opinion of the public on this issue is clearly not cut and dried and should not be taken for granted. For example, in a survey in 2007 on legitimacy and the House of Lords, 90 per cent of people felt it important (either very or fairly) that there were many experts in the House and a further 83 per cent that there should be 'numerous independent members'. ${ }^{139}$ These findings are, of course, hardly consistent with a wholly or largely elected House of Lords which would undoubtedly consist of a raft of professional politicians. As a fascinating aside, in December 2010 on the floor of the House of Lords, the fourth annual debate for young people (those most likely to be directly affected in the future by these reforms) debated the issue of Lords reform and voted for a fully appointed House of Lords. ${ }^{140}$

In short, it was imperative that a referendum should have taken place in order to have ascertained the view of the public on such a fundamental (and controversial) constitutional issue. After all, this was the only way in which the view of the people could have been gauged with precision. In any case, if the perceived prevailing public view was that it favoured an elected House of Lords (largely or wholly), what was the danger in testing that opinion in a definitive nationwide referendum? Furthermore, in a survey in late 2011, 63 per cent of people supported a referendum to determine the future of the House of Lords ${ }^{141}$ and, in April 2012, 72 per cent were in favour of a referendum on the Coalition

134 Brazier (n 62).

1352011 Elections and Referendum on the Voting System to the UK Parliament: Public Opinion Survey (ICM 2011) 17 and fig 4.3.

136 Tierney (n 34) 383.

137 Budge (n 133) 2.

138 House of Lords Select Committee on the Constitution (n 6) Q 221.

139 Meg Russell, The Contemporary House of Lords: Westminster Bicameralism Revived (OUP 2013) 248, table 9.8.

$140<$ www.parliament.uk>

141 Ian Cruse, Public Attitudes towards the House of Lords and House of Lords Reform (House of Lords Library Note 2012) 21. 
government's proposals for an 80 per cent elected House. ${ }^{142}$ Although the Coalition government dismissed the opportunity to hold a referendum in the last Parliament, any future proposal for major reform of the House of Lords should be accompanied by a commitment to stage a referendum in order to ascertain the view of the 'constituent power' on this fundamental issue. For one thing, such a referendum would (arguably) give authoritative and definitive clarification on this matter which, as detailed below, is the fourth reason a referendum should have been held by the Coalition government.

\section{Settling the issue}

The final argument, therefore, for holding a referendum was that it could have provided some much needed clarity on an issue which has dogged Parliament for decades. There has been no inter-House consensus on this matter as Parliament as a whole has failed (historically) to provide a clear steer as demonstrated by the votes in 2003 and 2007. Quite apart from the fact that the House of Commons in 2003 could not even agree to a reformed composition, in both 2003 and 2007, the House of Lords voted overwhelmingly for an appointed House. Even in terms of the votes in 2007 when the Commons did approve the two (albeit contradictory) options of the fully and 80 per cent elected models, it must be remembered that the majority of then Conservative MPs who voted did so against both. ${ }^{143}$ In any event, concern was expressed as to whether the vote for the fully elected House by MPs in 2007 was marred by tactical voting. ${ }^{144}$ In terms of consensus, the director of the Constitution Unit, Professor Hazell has observed that: 'All the parties are internally divided on Lords reform, with strong defenders of an elected or appointed House to be found spread across all parties.' ${ }^{\text {145 }}$ Rather pertinently, Butler and Ranney have argued that referendums have been useful in resolving questions which the representative institutions were unable to resolve. ${ }^{146}$

In December 2010 the then Minister of State at the Ministry of Justice, pointed out that the House of Commons had come to 'a settled and consistent view' of the need to reform the Lords and that these views were then taken to the electorate at the 2010 general election. ${ }^{147}$ As noted, the Coalition government dismissed calls for a referendum on the basis that all three political parties' manifestoes had agreed to reform the House of Lords. ${ }^{148}$ The following points, however, must be made. First, reform of the House of Lords comprised barely a few lines in each manifesto and the inherent flaw of the mandate doctrine is that the issue of Lords reform was subsumed within a sea of other disparate issues. Over a century ago, Professor Dicey recognised that it was impossible in a general election for electors to provide a satisfactory reply to an incongruous number of different issues $^{149}$ and that an election was not a judgment on the merits of a particular legislative proposal. ${ }^{150}$ In contrast, a referendum enables legislation to be separated from politics (in

$142 \mathrm{Ibid} 24$. It is also pertinent to remember that in 2011 the author lodged an e-petition on the HM government website calling for a referendum on whether the second chamber should be largely or wholly elected.

143 Ryan (n 15) 341.

144 Ibid 331.

145 Robert Hazell, The Conservative-Liberal Democrat Agenda for Constitutional and Political Reform (Constitution Unit 2010) 29.

146 Butler and Ranney (n 5) 263.

147 Lord McNally, HL Deb 1 December 2010, vol 722, col 1474.

148 Repeated by Mark Harper MP, Joint Committee on the Draft House of Lords Reform Bill (n 2) vol II Q 750.

149 Dicey, 'The Referendum and its Critics' (n 4) 547.

150 Dicey, 'Ought the Referendum to be Introduced into England?' (n 4$) 494$. 
other words, it enables the voter to be able to distinguish between 'men' and 'measures'). ${ }^{151}$ The importance of Lords reform warranted a stand-alone referendum in 2012 in which this issue should have been isolated and considered on its own merits.

Second, it is conceded that at the 2010 general election the manifestoes of the three main parties did coincide to the extent that they were in line with the two options approved by the Commons in 2007 (but not the Lords). It is, nevertheless, a fair question to ask as to how should a Conservative, Liberal Democrat or Labour voter - who wanted a fully appointed House - have voted at the 2010 general election. As Graham Brady MP pointed out during the second reading of the House of Lords Reform Bill, if all the 2010 manifestoes had effectively promised the measure, then the case for a referendum was compelling as the public had been presented with no choice. ${ }^{152}$ It is fascinating to record that an analogous situation occurred in relation to Europe at the 1970 general election when all three main parties had supported entry into the European Economic Community and so 'there was no way of telling whether the electorate supported what seemed to many the most important constitutional issue of the century'. ${ }^{153}$ In any case, Professor Bogdanor has also posited that, although an election provides a mandate to govern the country, it does not provide one to change the framework of the constitution. Such alteration required something more than a general election. ${ }^{154}$ What is also worth remembering is that from a constitutional perspective, the Coalition government's agreement of May 2010 for reform of the Lords was never expressly approved of - and so legitimised - by the public.

Third, in terms of detail, the 2010 manifesto commitments of the two parties in government were actually contradictory. As detailed earlier, whereas the Conservatives proposed to work towards a consensus on a (hybrid) largely elected chamber, the Liberal Democrats advocated a wholly elected House. The distinction between these two views was not a matter of degree, but instead one of kind. This matter was fudged at the outset by the Coalition government's programme 'for a wholly or mainly elected upper chamber', ${ }^{155}$ as if the difference between them was simply a matter of political judgment, rather than being entirely different constitutional propositions. For example, a wholly elected House would ipso facto have rendered both the bishops and a statutory Appointments Commission superfluous. In any event, in relation to the Conservative Party manifesto, it has been suggested that this was not actually a commitment to reform the Lords, but rather it 'gave a process commitment to seek dialogue to find common ground'. ${ }^{156}$

\section{The mechanics of a referendum}

Two final issues remain to be considered: if there had been a referendum on House of Lords reform in the last Parliament, what should the question have been and when should the ballot have been held? In terms of questions, the Select Committee was of the opinion that in a referendum there should be a presumption in favour of questions with two possible responses/options (but it did recognise that 'multi-option questions' might be preferable in some circumstances). ${ }^{157}$ In general, this is sensible as it aids clarity and avoids (typically) an ambiguous outcome. One of the difficulties with the issue of Lords reform, however, is that this debate is complex and multi-sided, which would have necessitated

151 Dicey, 'Ought the Referendum to be Introduced into England?' (n 4) 507.

152 HC Deb 9 July 2012, vol 548, col 63.

153 Bogdanor (n 55) 38-39.

154 Ibid 30.

155 The Coalition: Our Programme for Government (n 21).

156 Sadiq Khan, HC Deb 9 July 2012, vol 548, col 45.

157 House of Lords Select Committee on the Constitution (n 6) 38. 
multiple options being presented to the public (see the suggested prototype below). In any case, any referendum question(s) would have had to have been clear and non-leading, thereby following the guidelines of the Council of Europe. ${ }^{158}$ Under any referendum on Lords reform, it would have been the statutory responsibility of the Electoral Commission under s 104 of the Political Parties, Elections and Referendums Act 2000 to have considered and reported on the intelligibility of the question(s). In respect of supermajorities and voter-turnout thresholds, the Select Committee, quite rightly, recommended that there should be a general presumption against such devices. ${ }^{159}$

In terms of timing, the UK has had experience of both pre-legislative (e.g. 1997 Scottish devolution) and post-legislative (e.g. 1979 Scottish devolution) referendums. After the Joint Committee issued its report in April 2012 recommending a referendum, the ideal and optimum position would have been for the Coalition government to have piloted a House of Lords Referendum Bill through Parliament, paving the way for a national poll to have taken place. In other words, it is contended that the referendum should have been a prelegislative one which should have been held before the 2012 House of Lords Reform Bill was even introduced into Parliament (the result of which could possibly have even rendered the Bill redundant). It is suggested that this pre-legislative referendum would have invited the public to select from the following options: a wholly elected House; a hybrid House or an appointed House (the latter, in effect, representing the status quo). To avoid an ambiguous outcome, responses would have been ranked in preferential order (i.e. a 'preferendum'). ${ }^{160} \mathrm{~A}$ second question on the ballot paper would have distinguished between - and have asked the voter to rank in preferential order - three different types of hybrid options (i.e. a minority elected, half elected and largely elected). The responses to this second question would only have been considered in the event that the public had first indicated a preference for a hybrid chamber (i.e. question 1, option 2 above acting as a 'gateway'). An interesting example of a two-part referendum ballot paper (albeit non-preferential) was provided by New Zealand in its 1992 national referendum on its electoral system. ${ }^{161}$

One clear practical and political advantage of holding such a pre-legislative referendum would have been that it would have ameliorated any resistance in the House of Lords to any Bill proposing a largely or wholly elected second chamber. Objections to an elected House were made quite plain in the chamber in June 2011 during a 'Motion to take note debate' on the Draft Bill and White Paper. ${ }^{162}$ The political and practical reality in mid2012, however, was that any referendum would have had to have been post-legislative. This was implicitly recognised by the Joint Committee as it advised that a debate on the principle of staging a referendum be facilitated by the Coalition government before the committee stage of the Bill. ${ }^{163}$ It was plain that the Coalition government (no doubt the Liberal Democrat element of it) was anxious to proceed with legislating for reform, secure in the knowledge that recourse to the Parliament Acts could have been resorted to if necessary. Assuming that the 2012 House of Lords Reform Bill had gone on to receive the royal assent, the only practical question that could realistically have been asked in such circumstances was whether or not the public approved of the Act. In other words, the House of Lords Reform Act would have had to have contained a sunrise provision which

158 European Commission for Democracy through Law (Venice Commission), Code of Good Practice on Referendums (Council of Europe 2009) 3.1.c.

159 House of Lords Select Committee on the Constitution (n 6) 44.

160 Graham Smith, Beyond the Ballot (The Power Inquiry 2005) 81.

161 Report of the Commission on the Conduct of Referendums (n 41) 50-51.

162 HL Deb 21 June 2011, vol 728, and HL Deb 22 June 2011, vol 728.

163 Joint Committee on the Draft House of Lords Reform Bill (n 2) 95. 
would have meant that the legislation would only have been activated if the public had endorsed it in a referendum (known as a 'suspensive referendum'). ${ }^{164}$ Although the plans for long-term reform faltered in the last Parliament, it is argued that any future proposal for major Lords reform should be accompanied by a pre-legislative referendum following the two-question prototype detailed above.

\section{Conclusion}

In April 2012 the Joint Committee concluded its report by stating that in view of the significance of the constitutional change brought forward for an elected House of Lords, the Government should submit the decision to a referendum'. ${ }^{165}$ Although the Coalition government rejected this recommendation, a UK-wide referendum would, however, have been justified chiefly on the basis that the creation of a largely elected House of Lords would have represented a fundamental change to our constitutional arrangements. As a result, authority for such reform would have warranted explicit endorsement by the people through a specific mandate. A recent political precedent for a referendum had also been set by the national vote on the electoral system in May 2011. Such a referendum would also have avoided an insular parliamentary approach to Lords reform and thereby have enabled the wider public to impact directly on this crucial constitutional question. In the UK we have had experience of two UK-wide referendums and there was a clear and compelling case for a third one to take place - on completing the reform of the House of Lords. It is fascinating to conclude that we might have been closer to a referendum taking place than is perhaps realised. During the first day of the second reading of the 2012 House of Lords Reform Bill, although the then Deputy Prime Minister dismissed a referendum as unjustified, he did state that he would be prepared to consider one if MPs required assurances after the first tranche of members had been elected 'so that the second and third stages of reform are subject to some type of trigger'. ${ }^{166}$ The following morning in an answer to an oral question, however, he reaffirmed his opposition to a referendum. ${ }^{167}$ In the event, no provision for a referendum was made and two months later the Bill was abandoned leaving long-term reform of the House of Lords in abeyance and as elusive as ever. Nonetheless, should proposals for fundamental Lords reform surface in the future, the arguments advanced in this paper make a compelling case for a national referendum to take place.

164 European Commission for Democracy through Law (Venice Commission), Referendums in Europe: An Analysis of the Legal Rules in European States (Council of Europe 2005) 20.

165 Joint Committee on the Draft House of Lords Reform Bill (n 2) para 385.

166 HC Deb 9 July 2012, vol 548, col 36.

167 HC Deb 10 July 2012, vol 548, col 149. 
